УДК 123.1

DOI: $10.17223 / 1998863 X / 39 / 17$

\title{
О.Н. Дьяченко
}

\section{ФЕНОМЕН СВОБОДЫ В КОНТЕКСТЕ ЧЕЛОВЕЧЕСКОЙ ЛИЧНОСТИ В ГРЕЧЕСКОЙ ПАТРИСТИКЕ}

\begin{abstract}
Представлена трактовка феномена свободы в греческой патристике. Раскрытие сущности личностного в человеке, по мысли Восточных Отцов и Учителей Церкви, реализуется в устранении собственной воли, что равнозначно пониманию абсолютной свободы как таковой. Данная позиция формирует впоследствии принципиально разные направления в осмыслении человеческой личности в западноевропейской и византийской философии.

Ключевые слова: свобода, libertas, греческая патристика.
\end{abstract}

Отношение к свободе формирует два принципиально разных направления в артикуляции ключевых идей, касающихся осмысления феномена человеческой личности, оформившихся на латинском Западе и греческом Востоке. Ученик апостола Павла Дионисий Ареопагит, например, видел идеал свободы в полном устранении от всего, что существует в мире, что есть в самом человеке, в отказе от самого себя во имя единения с Богом, который свободен от всего и «превосходит любую сущность».

Однако подобная точка зрения, скорее, единична. В период ранней патристики христианские мыслители на Востоке выражают определенное единодушие в негативной трактовке свободы, достаточно вспомнить одно из часто встречающихся в творениях Отцов и Учителей определение «гибельная» свобода. Так, представитель александрийской школы Климент Александрийский, например, высказывает утверждение о том, что для человека, страдающего от собственных пороков, утрата свободы вовсе не означает бедственного и сокрушительного события в жизни, напротив, он должен воспринять свершившееся как подлинное благодеяние. Об этом греческий Учитель Церкви пишет в «Строматах».

Libertas осмысливается как испытание, выдержать которое человек оказался не способен. Свобода нередко воспринимается как источник греха и корень зла. И в качестве примера многие мыслители обращаются к ветхозаветному сюжету о грехопадении Адама.

В греческой патристике постепенно формируется стойкое убеждение в том, что свобода разрушительна для человеческой личности и духовного совершенствования. Отсюда основой аскетической практики, укоренившейся уже в IV веке в киновиях, оказывается фиксация внимания на отсечении собственной воли, что проявлялось в безоговорочном подчинении авве. И значительный пласт литературы периода патристики посвящен получению и описанию накопленных знаний о достижении одной из первостепенных задач в духовном опыте подвижника - искоренению собственной воли. Такая позиция в дальнейшем все более утверждается и повсеместно реализуется в практическом опыте жизни монашеских общин на Востоке. 
Свобода не таит в себе опасности для человека, когда подается Богом по мере духовного возрастания. Иначе она способна породить внутренние противоречия и искажения истины. Именно поэтому в творениях греческих Отцов и Учителей Церкви нередко звучат предостережения о недопустимости свободы мысленных представлений за границы того, что представлено в Священных текстах. Откровение - есть всякая мера в размышлении и предел дозволенного для мысли человека. Об этом пишет Василий Великий в беседах на Шестоднев, Иоанн Златоуст и другие христианские мыслители.

Свобода должна быть пленена умом. Кирилл Иерусалимский, а вслед за ним Иоанн Златоуст доказывают, что обретение подлинной свободы возможно при условии освобождения от заблуждений. Именно поэтому Григорий Нисский определяет «vo $\square$ », как сущностное свойство человека. И там, по его мнению, пребывает свобода, в которой заключена способность человека к самоопределению.

Но, несмотря на удивительное, на первый взгляд негативное однообразие мнений в понимании свободы, на Востоке предпринимаются попытки подвергнуть всестороннему рассмотрению данный феномен в контексте осмысления человеческой личности. Так, Григорий Назианзин, размышляя о свободе, объясняет, что «образ раба», который добровольно принял Христос, позволил человеку обрести подлинную свободу. Он доказывает, что Бог установил «закон свободы». «Законом же была заповедь: какими растениями ему пользоваться и какого растения не касаться. А последним было древо познания» [1. С. 666], - поясняет он. Свобода и сердечное расположение у Григория Назианзина есть необходимое условие не только всякого доброго дела, но и духовного совершенствования.

Эту идею повторяет и другой представитель каппадокийской школы Григорий Нисский. В работе, посвященной антропологическим вопросам, он поясняет: «Добродетель есть нечто неподвластное и добровольное, принужденное же и невольное не может быть добродетелью» [2. С. 84]. Мысль о свободе в добродетели присутствует и у Иоанна Златоуста в «Беседах на книгу Бытия».

Но существует еще одно качество, о котором упоминает подавляющее большинство представителей греческий патристики, без него невозможно не только обретение подлинной свободы, но и личностное совершенствование и духовное возрастание - это избавление от страха. Именно поэтому уже в трактатах мыслителей данного периода постулируется свобода от страха как такового, и возникает новое понятие «страх Божий», который заключается в боязни и непринятии греха, что предполагает следование заповедям. Так, Климент Александрийский поясняет: «В действительности, это не страх Бога, но страх потерять его. Страх такого рода - это страх оказаться в путах зла, страх злого» [3. Т. 1. С. 91]. Страх Божий - это своего рода добродетель, как то, что избавляет человека от зла. Обретение страха Божьего, по мысли многих греческих Отцов, приносит душе внутреннее состояние мира и освобождения.

Вместе с тем у Восточных Отцов и Учителей Церкви существуют мнения, которые выделяются из общей канвы размышлений о феномене свободы в контексте понимания человеческой личности. Интересную мысль высказыва- 
ет Василий Великий. Он настаивает на том, что существует общее для всех людей свойство. Так, никто из живущих не может быть свободен от страха.

Самобытные, но весьма противоречивые суждения мы находим у Исаака Сирина, который отрицает наличие совершенной свободы в дольнем мире. До своего грехопадения мир был совершенен, а человек обладал абсолютной свободой. Но, утратив ее, мир изменился. В некотором смысле Исаак Сирин повторяет мысль Дионисия Ареопагита, говоря о том, что свобода ума есть подлинный пусть к свободе души.

Интересно, что Ефрем Сирин в одном из своих сочинений говорит о свободе от страдания, но его мысль представляется достаточно неоднозначной, поскольку не согласуется с христианским мировосприятием.

Но вместе с тем существует одно положение, которое часто фигурирует и у западных, и у восточных мыслителей, - достижение свободы от привязанности к миру и всего, что его наполняет. Об это ясно говорит Августин и повторяет в своих наставлениях Антоний Великий, поясняя, кого надлежит называть «истинно свободными»: «...знатных и богатых, когда они злы и невоздержны, потому что такие суть рабы чувственных страстей. Свободу и блаженство души составляют настоящая чистота и презрение привременного» [4. С. 64]. Кроме того, в размышлениях философов периода патристики как на Западе, так и на Востоке можно встретить вполне античную трактовку феномена человеческой свободы, как и то, что наличие или невозможность выбора совсем не означает отсутствия свободы.

Представитель греко-восточной культуры Немесий Эмесский определяет путь освобождения души раскаянием, который возможен только для человека. В этом он находит его преимущество перед другими сотворенными существами, например силами ангельскими. Возможность свободного избрания обязательная ступень всякого действия, поэтому это и есть начало как добродетели, так и порока. Следовательно, источник зла заключается не в наличии свободы как таковой, а в том, что существует выбор. На этом вопросе Немесий подробно останавливается в своем трактате «О природе человека» [5]. В некотором роде его мысль повторяет и Максим Исповедник. Он доказывает, что свобода воли заключается не в свободе выбора, но в освобождении души от естественных, плотских уз, от связей с миром, что позволяет ей об-

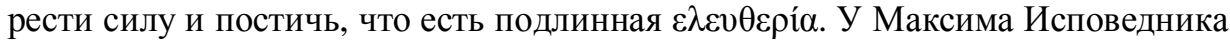
сохраняется прямая связь между действиями разума и волей. Поэтому он и указывает на то, что само мышление человека суть множественность, опосредованное соединение разнообразных крайностей и противоположностей, заключающее в себе «связь мыслящего и мыслимого» [6. С. 308]. Соответственно, выбор предполагает отсутствие ясности, сомнение, искание, а значит, допускает противоречия, ведущие к разделению, к неполноте и нетвердости воли. Движение воли в актах свободного избрания он относит к искажению свободы. Истинная $\varepsilon \lambda \varepsilon v \theta \varepsilon \rho i ́ \alpha$ предполагает целостность, неизменность интенции воли, влекущих душу к Богу. Именно утрата подлинной свободы, целостности, которая являлась стержнем образа личности, привела человека к падению.

Конечно, нельзя не признать, что в вопросе определения сущности свободы воли очевидно влияние Максима Исповедника и восточно-христианской 
мысли, которое испытал Иоанн Скот Эриугена. Именно поэтому философ обращается в большей степени не к проблеме соотношения свободы воли и Божественной благодати, характерной для средневековой западной философии, а к ее свойствам, на которых он подробно и останавливается. Суждения Эриугены, касающиеся феномена человеческой воли, представлены в «Упорядоченном комментарии ко второй книге «Сентенций» Петра Ломбардского» [7], которые приводит Г.Г. Майоров. В данном трактате философ говорит о двух силах человеческой души: воле и разуме, который он ставит в зависимость от воли. Главное, что отличает его понимание от других средневековых мыслителей, заключается в том, что воля не может распознавать, что есть благо, хотя она стремится к добру по своей природе.

Многие представители греко-восточной средневековой философской мысли соединяли свободную волю и разум, выражая единство мнений в том, что они тесно связаны друг с другом. Никто из представителей Средневековья не пытался ответить на вопрос: почему свободная воля всегда остается и у человека, лишенного разума? Ведь, очевидно, такое возможно.

На основании вышесказанного следует, что в работах западных мыслителей периода патристики в контексте проблемы личности ключевым выступает вопрос соотношения Божественной благодати и свободы воли (достаточно вспомнить широко известную полемику Августина с Пелагием), у греческих Отцов и Учителей Церкви центральной оказывается идея искоренения собственной воли и достижение стремления жить по воле Божьей.

И если в западноевропейской средневековой философии идет речь о признании человеком своей зависимости от воли Бога, которое понимается как подтверждение его свободы, то в греко-восточной мысли, при всем многообразии смыслов, которое открывается в трактатах Отцов и Учителей Церкви, абсолютный идеал, раскрывающий однозначное представление о свободе, совершенстве воли и ее сущности в контексте понимания личности, дан в речи Христа о чаше «не Моя воля, но Твоя да будет» (Лк.22:42). Раскрытие онтологической первоосновы человеческого бытия, сущности личностного в человеке, выявление внутренних основ его личности возможны только при полном устранении собственной воли, что и равнозначно пониманию абсолютной свободы как таковой.

Свобода в западноевропейской философской традиции никогда не воспринималась как источник зла, в то время как в греко-восточной мысли свобода есть корень всех несчастий человека, с другой стороны, свобода есть некий императив существования добра и личностного совершенствования. Именно поэтому у Максима Исповедника идет речь о том, что зло есть отрицание чистой возможности свободы. Libertas получает свое практическое осуществление в жизни человека только благодаря его личной ответственности, в самоотречении от собственного волеизъявления, что предуготовляет душу человека к тому, чтобы стать «достойной свободы».

\section{Литература}

1. Творенія иже во святыхъ отца нашего Григорія Богослова, Архиіпископа Константинопольскаго. Слово 45. Слово на святую Пасху. СПб.: издательство П.П.Сойкина, 1912. Т. І. C. 661-680.

2. Григорий Нисский. Об устроении человека. СПб.: Аксиома, 1995. 174 с. 
3. Климент Александрийский. Строматы / подгот. текста, пер. с древнегреч, предисл. и коммент. Е.В. Афонасина. СПб.: Изд-во Олега Абышко, 2003. Т. І: Книги (1-3). 544 с.

4. Антоний Великий. Наставления о доброй нравственности и святой жизни, в 170 главах. Добротолюбие. М.: ООО «Издательство АСТ»; Харьков: Фолио, 2001. С. 60-88. $464 \mathrm{c}$.

5. Немесий Эмесский. О природе человека. М.: «Канон+», РООИ «Реабилитация», 2011.

6. Преподобный Максим Исповедник. Главы о богословии и о Домостроительстве воплощения Сына Божия. Избранные творения. М.: Паломникъ, 2004. 496 с.

7. Майоров Г.Г. Философия как искание Абсолюта: Опыты теоретические и исторические. Изд. 2-е. М.: Книжный дом «ЛИБРОКОМ», 2009. 416 с.

Olga N. Dyachenko. Kursk Institute of Development Education (Kursk, Russian Federation)

E-mail: dyachenkoolga13@yandex.ru

DOI: $10.17223 / 1998863 X / 39 / 17$

THE PHENOMENON OF FREEDOM IN THE CONTEXT OF THE HUMAN PERSON IN THE GREEK PATRISTIC

Key words: freedom, libertas, Greek patristic

Attitude towards freedom creates two fundamentally different directions in the articulation of the key ideas for understanding the phenomenon of the human person, to issue in the Latin West and the Greek East.

Representatives of the Greek patristic express a specific unanimity in the negative interpretation of freedom, which receives the name of «disastrous» and is perceived as the source of sin and the root of all evil. Libertas is interpreted as a test to overcome that man was not capable of. As an example, many thinkers turn to the Old Testament story of the Fall of Adam.

In Greek patristic gradually formed a firm conviction that freedom is destructive to human personality and spiritual development. Therefore, the foundation of ascetic practices, rooted in the IV century kin, is the fixation of attention on cutting off their own will, the subject, which is dedicated to a significant body of literature of the period. Freedom is not fraught with the danger to humans when fed by God as spiritual growth.

However, the freedom and the location of the heart in representatives Cappadocian schools is a necessary condition not only to every good work, and spiritual development.

In the treatises of thinkers of the patristic period postulated freedom from fear, and there is a new concept of «fear of God», that is, sin and failure to follow the commandments.

However, in the Greek patristic there are opinions that stand out from the canvas thinking about the phenomenon of freedom in the context of understanding the human person: the denial of freedom within the boundaries of the world partite (Isaac the Syrian), the idea of freedom from suffering (Ephraim of Syria).

The concept of Maximus the Confessor loss of true freedom, that is integrity, which is the core image of the personality, led to the fall of man.

General at the western and eastern representatives of patristic is the idea of freedom from attachment to the world and all that fills it.

In the works of Western thinkers of the patristic period, in the context of the individual key advocates question the relation of divine grace and free will, the Greek - is the central idea of his own will to achieve eradication and desire to live according to God's will. Disclosure of the ontological foundation of human existence, the essence of personality in man, identifying the internal foundations of his personality is possible only if the full elimination of their own will, and that is equivalent to the absolute understanding of freedom as such.

\section{References}

1. Gregory of Theologian. (1912) Tvoreniya izhe vo svyatykh" ottsa nashego Grigoriya Bogoslova, Arkhiipiskopa Konstantinopol'skago [Works of Grigoriy the Theologian, Archbishop of Constantinople]. Vol. 1. St. Petersburg: P.P.Soykin. pp. 661-680.

2. Gregory of Nyssa. (1995) Ob ustroenii cheloveka [On the Making of Man]. St. Petersburg: Aksioma.

3. Clement of Alexandria. (2003) Stromaty [Stromata]. Translated from Old Greek by E.V. Afonasin. Vol. 1. St. Petersburg: Oleg Abyshko. 
4. Anthony the Great. (2001) Nastavleniya o dobroy nravstvennosti i svyatoy zhizni, $v 170$ glavakh. Dobrotolyubie [Instructions on Good Morality and Holy Life, in 170 chapters. Philokalia]. Moscow: AST; Kharkov: Folio. pp. 60-88.

5. Nemesiy of Emes. (2011) O prirode cheloveka [About the Nature of Man]. Moscow: Kanon+, Reabilitatsiya.

6. The Monk Maximus the Confessor. (2004) Glavy o bogoslovii i o Domostroitel'stve voploshcheniya Syna Bozhiya. Izbrannye tvoreniya [The Chapters on Theology and the House-Building of the Incarnation of the Son of God. Selected Works]. Moscow: Palomnik".

7. Mayorov, G.G. (2009) Filosofiya kak iskanie Absolyuta: Opyty teoreticheskie i istoricheskie [Philosophy as the Search for the Absolute: Theoretical and Historical Experiments]. 2nd ed. Moscow: LIBROKOM. 